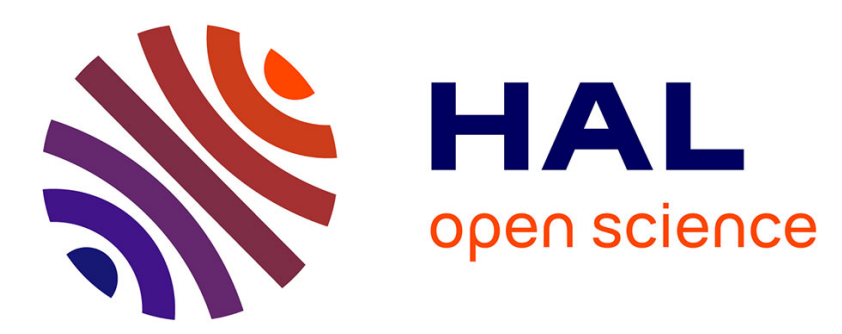

\title{
Remittances and Business Cycles: Comparison of South Asian Countries
}

Mazhar Mughal, Junaid Ahmed

\section{To cite this version:}

Mazhar Mughal, Junaid Ahmed. Remittances and Business Cycles: Comparison of South Asian Countries. 2013. hal-01885151

\section{HAL Id: hal-01885151 \\ https://hal-univ-pau.archives-ouvertes.fr/hal-01885151}

Preprint submitted on 28 Sep 2020

HAL is a multi-disciplinary open access archive for the deposit and dissemination of scientific research documents, whether they are published or not. The documents may come from teaching and research institutions in France or abroad, or from public or private research centers.
L'archive ouverte pluridisciplinaire HAL, est destinée au dépôt et à la diffusion de documents scientifiques de niveau recherche, publiés ou non, émanant des établissements d'enseignement et de recherche français ou étrangers, des laboratoires publics ou privés. 


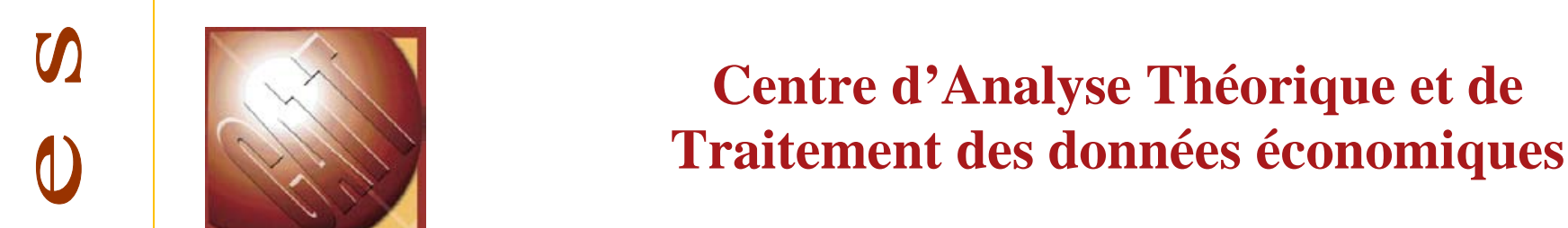

0

CATT WP No. 4 January 2013

REMITTANCES AND BUSINESS CYCLES: COMPARISON OF SOUTH ASIAN COUNTRIES

Mazhar MUGHAL Junaid AHMED 


\title{
Remittances and Business Cycles: Comparison of South Asian Countries \\ January 2013 \\ Mazhar Mughal and Junaid Ahmed
}

\begin{abstract}
:
South Asia is one of the world's principal remittance-receiving regions. This study examines the home and host business cycles of migrant remittances to the region. Employing Structural VAR, the remittance behaviour of the region's four main countries is compared. Remittances to India and Pakistan show a mainly acyclical behaviour with respect to the output of the four host regions, and a countercyclical one with the home output. In contrast, remittances to the two smaller economies of Bangladesh and Sri Lanka are found to be mainly procyclical. The study shows that remittance behaviour varies with respect to the importance of remittance flows in the home economy. Moreover, remittance behaviour seems to respond more to home economy specificities than to those of the different regions hosting the migrants from the developing country.

JEL codes: E32, F15, F22, F24.

Key words: Remittances; Business Cycles; South Asia; Bangladesh; India; Pakistan; Sri Lanka; SVAR.
\end{abstract}




\section{Introduction}

South Asia is one of the principal remittance-receiving regions in the world, accounting for about a quarter of global migrant remittance inflows (World Bank 2012). Four of the region's countries: India, Pakistan, Bangladesh and Sri Lanka consistently rank in the world's top twenty recipients in absolute terms, while Nepal is one of the major recipients of remittances in terms of GDP. The recorded remittance inflows to South Asia have maintained a sustained growth in recent years, increasing annually by 18 percent from $\$ 72$ billion in 2008 to $\$ 97$ billion in 2011 (World Bank, 2012). Among the South Asian countries, India remains the topmost recipient of remittances among the developing nations with remittances amounting $\$ 64.0$ billion in 2011. Bangladesh and Pakistan each received $\$ 12$ billion. The volume of officially recorded remittances to the region has exceeded FDI, portfolio and official development inflows for many years.

As a result, the countries of the region rely highly on remittances for fulfilling their foreign exchange needs. This reliance increases further when the regional economies are facing economic difficulties at home. It is therefore imperative to know how remittances interact with the macroeconomy. Are they procyclical, i.e. moving in tandem with the economy, countercyclical, i.e. moving oppositely to the aggregate output, or acyclical, i.e. showing no association with the country's economic performance?. This study is an attempt at finding these cyclical properties of remittance inflows to South Asia. Though some country studies exist on the topic (for example Ahmed (2012) in case of Pakistan, Gupta (2005) in case of India, and Lueth and Ruiz-Arranz (2007) in case of Sri Lanka), to the best of our knowledge, no comprehensive and comparable empirical study exists on the regional level. Previous studies dealing with other countries and regions, such as Akkoyunlu and Kholodilin (2008) and Sayan and Tekin-Koru (2010) On Turkey, Vargas-Silva (2008) on Mexico and Giuliano and Ruiz-Arranz (2009) on a host of developing countries have come up with varying remittance association with home and host country business cycles, depending on the country and period examined and empirical techniques employed.

In this study, we investigate the relationship of official remittance flows to Bangladesh, India, Pakistan and Sri Lanka, as well as the aggregate flows to the region with both the home as well as the host economies. South Asian countries hold a diverse migration and remittance profile, with migrants spread all over the world. A contribution of this study is that remittances to South Asian countries are examined with respect to the four migrant-hosting regions which account for the bulk of remittances to South Asia. These regions are the Persian Gulf, North America, Europe, and Asia Pacific. We employ several empirical techniques for this purpose, and check for the robustness of our results. We are interested in finding answers to the following questions:

What has been the cyclical behaviour of remittances to South Asia during the last four decades?

How have the region's four major countries (India, Pakistan, Bangladesh and Sri Lanka) contributed to this behaviour?

What role has the home economic output played in driving remittance flows to the region?

What has been the association with host economies?

We seek to understand key features of the region's remittance profile in the light of these answers. In doing so, we also observe to what extent the region's economies are synchronized with their main remittance-sending regions.

In the next section, we describe the flow of remittances to the region in the past. Section 3 briefly overviews the literature on remittances' business cycle properties. Data and methodology are explained in section 4 . Section 5 presents the detrended cycles and their 
correlation with home and host output. Section 6 describes the findings of the Structural VAR model, as well as the resulting Impulse Response Functions and Variance Decomposition. Section 7 concludes.

\section{Migration and Remittances to South Asia - Some Salient Features}

Indian Sub-continent has long been a major source and destination for international migration. Historic South Asian communities can be found from South East Asia to East Africa and from the Caribbean to the Pacific. Indian immigrant community is the largest of all the region's overseas communities, with Non Resident Indians (NRIs) numbering 25 million (Ministry of Overseas Indian Affairs MOIA 2009). Other major migrant communities include 7 million Pakistanis (Ministry of Finance, Pakistan 2010), 5.38 million Bangladeshis (World Bank 2011) and 1.6 million Srilankans (Arunatilake et al. 2010). Although the region receives remittances from these migrants residing all over the world, four regions, those of Persian Gulf, North America, Europe and East Asia and Pacific, account for the bulk of inflows. In recent times, the first major wave of emigration from South Asia began in the 1970s when hundreds of thousands of semi and unskilled workers left the region to work in the oil economies of the Persian Gulf. The resulting remittance flows from these mostly temporary migrants became, for the first time, an important source of foreign exchange for the migrantsending countries. For instance, remittances exceeded 10 percent of Pakistan's output in 1983 (Mughal 2012). Growth of these remittance flows slowed in the 1990s, to revive during the boom years of 2000s. The South Asian migrant community in the OECD countries, especially in USA and Canada, grew substantially during the 1990s thanks to the emigration of thousands of professionals in Information Technology, health and engineering sectors. Remittances from the North American corridor rose sharply during the last decade, and now constitute the second major source of formal remittances to South Asia.

Besides the two aforementioned regions, Europe and East Asia and Pacific too account for a significant proportion of remittance flows to South Asia. In Europe, bulk of remittances comes from the United Kingdom, the country being host to a sizeable Asian community.

Remittances are playing an increasingly important role in South Asian economies. For example, as shown in table 1, international remittances to Nepal exceed 22 percent of its GDP, making it the regional leader, followed by Bangladesh and Sri Lanka, which respectively receive remittances equivalent to 11 and 8 percent of the GDP. The two large regional economies, India and Pakistan, respectively receive foreign remittances equivalent to 3 and 6 percent of their national output. The proportion of region's remittances with respect to the current account deficits has been growing, and represents an increasing dependence on the flows for covering foreign exchange requirements.

Table 1. Migrant's Remittances Inflow to South Asia (as a \% of GDP)

\begin{tabular}{l|cccc}
\hline & $\mathbf{1 9 8 0}$ & $\mathbf{1 9 9 0}$ & $\mathbf{2 0 0 0}$ & $\mathbf{2 0 1 0}$ \\
\hline India & & & & \\
Pakistan & 1.28 & 0.73 & 2.71 & 3.21 \\
Bangladesh & 8.64 & 5.01 & 1.45 & 5.48 \\
Sri Lanka & 1.87 & 2.59 & 4.18 & 10.81 \\
Nepal & 3.77 & 4.99 & 7.14 & 8.38 \\
\hline
\end{tabular}

Source: World Development Indicators, World Bank 2012

Country-wise distribution of remittance flows to the region has greatly evolved in the last three decades. In the 1980s, about half of the region's remittances went to Pakistan, while in 
the 2000s, India accounted for over half the region's total receipts. These flows make up a third of export receipts in case of India, and over half in case of other countries.

In addition to the four abovementioned destination regions, millions of unregistered Bangladeshis and Nepalis live in India and Pakistan, and their mostly unrecorded remittances form an important source of earning for the households back home. Most of the migrants from South Asia come from rural areas, and often belong to low-income households (Hasan 2006). The money they remit leads to lower poverty and reduces consumption inequality (Anwar and Mughal 2012, World Bank 2006). Barua et al, 2007 for Bangladesh and Nishat and Bilgrami (1993), Anwar and Mughal (2012) in case of Pakistan suggest the significance of altruistic remittance motives. This means that migrants prefer to remit in the times of crises at home. Remittances have also proven to be a relatively stable source of financing (Gopalan and S. Rajan 2009, Mughal and Makhlouf 2011), and have helped the households cope up with natural catastrophes (Savage and Harvey 2004, Suleri and Savage 2006). Remittances have led to higher economic growth in Bangladesh and Sri Lanka (Siddique et al. 2010). However, remittances do not appear to have significantly contributed to India's growth. Overall, Cooray (2012) finds positive and significant effect of remittances on the region's economic growth.

\section{Migrant remittances and Business Cycle: Review of Literature:}

A sizeable literature on the business cycle properties of remittances has developed in the last decade. Several studies have attempted to estimate the relationship between aggregate or bilateral remittance flows with home and host-economy output fluctuations. Neagu and Schiff (2009), for instance, study stability, cyclicality and stabilization impacts of migrant remittances in 116 developing countries, employing annual data for the period 1980-2007. They find remittances to be pro-cyclical in 65 percent of cases. Moreover, they show that Official Development Assistance is more stable than remittances, and in turn, remittances are more stable than FDI. Similarly, Giuliano and Ruiz-Arranz (2009) analyze the cyclical components of remittances and output series employing the HP filter. They conclude that remittances are pro-cyclical for about two-thirds of the countries included in the sample, while for the remaining countries remittances are counter-cyclical with respect to domestic economy output. In the same vein, Sayan (2006) studies the behaviour of migrant remittance flows for 12 developing countries. Using polynomial fitting model for the period 1976-2003, the author computes contemporaneous cross-correlation and asynchronous correlation coefficients using only the cyclical components and finds that aggregate remittance to the group of countries in the sample move counter-cyclically with output. Furthermore, at the individual country level, the flows of remittance are counter-cyclical for some countries whereas for others remittances are pro-cyclical or acyclical. Lueth and Ruiz-Arranz (2006) estimate a gravity model for migrants' remittances to a sample of developing countries, and come up with a different conclusion. They find that in the wake of a natural disaster, remittances do not seem to increase and appear to be aligned with the home-country business cycle, suggesting that remittances may not play a major role in restraining vulnerability to shocks. However, they do not seem to respond to adverse shocks when the investment and political climate worsens at home. In another study Frankel (2009), using the same datasets of bilateral remittances suggests that migrants' remittances sometimes play a stabilizing role in the home countries, though this effect is not applicable to all the countries examined. Among country-level studies, Bora Durdu and Sayan (2008) analyze the implications of remittance fluctuations for various macroeconomic variables. The authors develop a small-open economy two-sector model with financial frictions calibrated to Mexican and Turkish economies. Using quarterly data from the 1980s, they find that remittance flows to Mexico from the United States are counter-cyclical to the Mexican business cycle, whereas Turkish remittances are pro-cyclical and follow the Turkish business cycle with a one-quarter lag. In essence, their 
empirical results indicate that remittances dampen home business cycles in Mexico and amplify them in Turkey. Likewise, Sayan (2004) investigates the cyclical behavior of Turkish migrants' remittances with respect to the Turkish and German output quarterly data from 1987:1 to 2001:4. He reports that Turkish remittances are procyclical to real GDP in Turkey but appear to be acyclical to the German output. Remittances appear to constitute a very important source of income for Turkey, but do not appear as a stabilization instrument against macroeconomic shocks. On the other hand, Akkoyunlu and Kholodilin (2008) come up with very different conclusions. They use annual data covering 1962 to 2004 and divide the original sample into recruitment, family reunification and naturalization periods. Using cross-correlation and bi-variate vector auto-regression, they find that remittances respond acyclically to changes in the home-country economic activity, and pro-cyclically to those in the host country. Still different results are reported by Coronado (2009) who analyzes the business cycle properties of remittances and output series for United States-Mexico, the United States-El Salvador, and Germany-Turkey remittance corridors using an unobserved components state-space model (with Beveridge-Nelson decomposition). The results show that remittances are counter-cyclical with respect to all the three home countries: Mexico, El Salvador, and Turkey. However with respect to source countries, remittances to Mexico are counter-cyclical with respect to the US business cycle, while those from United States to El Salvador and Germany to Turkey are strongly pro-cyclical with output fluctuations in the source countries. Vargas-Silva (2008) show that remittances are countercyclical with respect to Mexican business cycle but this result is not robust in using different measures of remittances. However, he founds strong coherence between remittances and US business cycle.

A few studies have examined the cyclical behaviour of remittances to South Asian countries. Lueth and Ruiz-Arranz (2007), for instance, explore to what extent migrant remittances have helped Sri Lanka against macroeconomic shocks. Employing quarterly data for the period 1996-2004, they estimate a vector-error-correction (VEC) model to determine the response of remittance receipts to shocks in macroeconomic variables. They find that remittances are procyclical and decline when the island's currency weakens undermining their usefulness as shock absorbers. On the other hand, remittances increase in response to oil price shocks. Sayan (2006) finds that remittances to Bangladesh are countercyclical, whereas in India, remittances are countercyclical, though with a one-year lag. Ahmed (2012) examines the business cycle properties of remittance inflows to Pakistan. He finds that remittances to Pakistan act countercyclically with respect to the home output and consumption, whereas their behaviour with respect to the annual output of two major host economies, United States and United Kingdom, is acyclical.

In all, remittances appear to be countercyclical with respect to most of the home economy business cycles, while evidence on host economies is quite mixed. In the following sections, we attempt at finding the behaviour of remittance inflows to South Asia with their home and host economic cycles.

\section{Data and Methodology:}

\subsection{Data:}

The database used in this study contains annual time-series data from the period spanning from 1975 to 2011. We employ remittance and country annual output data for this study. Home economy output is represented by the respective country's Gross Domestic Product, while host economy output for each of the four host regions is calculated as the weighted sum 
of GDPs for all the respective region's constituent countries ${ }^{1}$. The aggregate real GDP for the whole group is obtained by weighting yearly outputs of individual countries in the sample with their average shares in the total real GDP. All data come from the World Bank World Development Indicators (WDI) data and the central banks of the home countries. The variables are expressed in millions of US dollars, and are converted from current US dollars into constant 2000 US dollars by using respective CPI and GDP deflator for each country. In addition, all data are log transformed.

\subsection{Methodology:}

Our methodology consists of three steps. In the first step, we detrend our time series using different filtering techniques. Secondly, we check the cross-correlation between these detrended series. In the third step, we use Structural Vector Autoregression to reach causal inference following Bernanke (1986) and Sim (1986) short-run restriction framework and obtain Impulse Response Functions (IRF) and variance decomposition. Given that SVAR is the mainstay of our empirical strategy, we first mathematically derive the method before presenting its findings.

\subsubsection{Time Series Filters}

In order to observe the behavior of time series business cycle frequencies, it is common practice to de-trend the series by employing various filters. These filters eliminate the slowlyevolving, long-term ("trend") component and the rapidly-varying ("irregular") component of a variable, leaving behind the intermediate-term ("business-cycle") component of variable (Baxter and King, 1999). In this study we take a skeptical approach to this problem: none of the filtering methods employed is exclusively supposed to be adequate. Instead, following Canova (1998), we assume that all procedures are approximations which isolate different aspects of the trend and cyclical components of the series and leave behind the intermediate components. In what follows, we employ three filters: Hodrick and Prescott (1997) a high pass filter, the Baxter and King (1999) a band pass filter and Ouliaris and Corbae (2002) frequency domain filter. A serious concern with the application of a filter is the so-called 'end-point problem', which arises because the addition of new or revised observations changes the filtered values of previous observations. HP filter is more sensitive to the end values than band pass filters e.g BK and CF filter (Henk K et.al, 2004).

In our study, although we carry out our estimations using the three filters, we present and discuss mainly the findings of the Frequency Domain (FD) filter. This is because the Ouliaris and Corbae (2002) Frequency Domain filter is considered to perform better than the Hodrick and Prescott and Baxter and King (BK) filter, as it overcomes some of the shortcomings of the Hodrick and Prescott (1997) and Baxter and King time (1999) domain based filters. The results of $\mathrm{HP}$ and BK filters are available upon request.

To examine the existence of stochastic non-stationarity in the series, we establish the order of integration of individual time series through unit root tests. We use Augmented Dickey-fuller (ADF) test for this purpose. The series are: remittance inflows to the home economy $\left(X^{r e m}\right)$, output of host $\left(Y^{\text {host }}\right)$ countries and output of the home $\left(Y^{\text {home }}\right)$ countries. The results indicate that all the series are integrated of order one I $(1)^{2}$. All series are non-stationary at levels, but

\footnotetext{
${ }^{1}$ we separated the host economies into four major geographic regions, namely North America(USA, Canada), GCC(Saudi Arabia, United Arab Emirates, Kuwait, Qatar, Bahrain, Oman ), Europe(United Kingdom, Germany, France, Italy, Netherland, Spain, Greece, Belgium, Ireland, Switzerland, Sweden, Denmark, Norway), and Asia Pacific (Japan, Australia, Singapore, Hong Kong, Malaysia, New Zealand).

${ }^{2}$ The results are available upon request.
} 
the detrended series are stationary at levels. For the HP, BK and FD filters, the variables are stationary with a confidence interval of 99 percent, except for some variables which are stationary at 95 percent confidence level. The tests are presented in table A1 in the appendix.

\subsubsection{Cross-Correlation:}

Next, we conduct correlation analysis. First, using the Augmented Dickey Fuller (ADF) test, we find that the cyclical components of the series are stationary at levels ${ }^{3}$. We report both contemporaneous and asynchronous cross-correlations between the cyclical components of the two series. The series $x_{t}$ are said to be counter-cyclical (pro-cyclical) with the movement of cyclical component of the series if the contemporaneous correlation between the two series is negative (positive) and statistically significant. If coherence is absent, then the two series are considered acyclical. In our study, the variable $x_{t}$ is pro-cyclical (countercyclical) with $y_{t}$ if $0.32 \leq|\rho(0)|<1$ (Kydland and Prescott [1990], Pallage and Robe [2002], Alper [2001]). In addition to computing the asynchronous correlation between the cyclical components of $y_{t}$ and $x_{t}$, we shifted the later for one to two years in both directions. An analysis of the resulting coefficients of cross-correlation allows us to identify possible phase shifts by looking at how early or late the highest correlation appears relative to contemporaneous period (Pallage and Robe, 2002). For instance, $x_{t}$ is considered to lead the cycle by j periods if the significant $|\rho(j)|$ is maximum for a negative $j$ (i.e the lagged value of $x_{t}$ ), coincidental if $|\rho(j)|$ is maximum for $j=0$ and lags the cycle if maximum $|\rho(j)|$ arises for positive $\mathrm{j}$ (i.e the lead value of $x_{t}$ ).

\subsubsection{Structural VAR (SVAR):}

Structural VAR is widely used in the empirical literature to distinguish the effects of endogenous disturbances within a system. The aim of a structural VAR is to use economic theory rather than Cholesky decomposition to recover structural innovations from the residuals of a reduced-form VAR. A VAR is an n-equation, n-variable linear model in which each variable in turn by its own lagged values, current and past values of the remaining n-1 variables. According to Sims (1980), all variables should be treated on equal footing if there is simultaneity among a set of variables. There should not be any a priori distinction between endogenous and exogenous variables (Gujarati; 2004 p.848). An important decision before estimating the VAR model is the selection of maximum lag. Adding too many lagged terms can cause an insufficient degrees of freedom problem. However, adding too few lags can lead to specification errors ${ }^{4}$. The subsequent recognition of the VAR models still requires identifying assumptions ${ }^{5}$. A variety of structural VAR models have been proposed, either supporting short-term constraints (Bernanke, 1986, Blanchard and Watson, 1986, Sims, 1986), or long-term restrictions (Blanchard and Quah, 1989), or a combination of both short-term and long-term restrictions (Gali, 1992). The main objective of a structural VAR estimation is to obtain non-recursive orthogonalization of the error terms for impulse response analysis. This alternative to the recursive Cholesky orthogonalization requires the imposition of sufficient restrictions to identify the orthogonal (structural) components of the error terms.

To implement the SVAR methodology, let start with a simple VAR model:

\footnotetext{
${ }^{3}$ All original series were non-stationary before detrending. Test results are reported in appendix.

${ }^{4}$ The decision of the appropriate lag length is made using the criterion of Akaike, Schwarz, Hannan-Quinn, and Final Prediction Error. The model with lowest criteria is selected.

5 The "identification problem" calls for imposing restrictions on some of the structural parameters. The identification through Cholesky decomposition is considered a mechanical technique that some believed is unrelated to economic theory.
} 


$$
\begin{aligned}
& Y_{t}^{\text {host }}=b_{10}-a_{12} Y_{t}^{\text {home }}-a_{13} X_{t}^{\text {rem }}+\sum_{i=1}^{p} b_{11}^{i} Y_{t-p}^{\text {host }}+\sum_{i=1}^{p} b_{12}^{i} Y_{t-p}^{\text {home }}+\sum_{i=1}^{p} b_{13}^{i} X_{t-p}^{\text {rem }}+\varepsilon_{t}^{\text {host }} \\
& Y_{t}^{\text {home }}=b_{20}-a_{21} Y_{t}^{\text {host }}-a_{23} X_{t}^{\text {rem }}+\sum_{i=1}^{p} b_{21}^{i} Y_{t-p}^{\text {host }}+\sum_{i=1}^{p} b_{22}^{i} Y_{t-p}^{\text {home }}+\sum_{i=1}^{p} b_{23}^{i} X_{t-p}^{\text {rem }}+\varepsilon_{t}^{\text {home }} \\
& X_{t}^{\text {rem }}=b_{30}-a_{31} Y_{t}^{\text {host }}-a_{32} Y_{t}^{\text {home }}+\sum_{i=1}^{p} b_{31}^{i} Y_{t-p}^{\text {host }}+\sum_{i=1}^{p} b_{32}^{i} Y_{t-p}^{\text {home }}+\sum_{i=1}^{p} b_{33}^{i} X_{t-p}^{\text {rem }}+\varepsilon_{t}^{\text {rem }}
\end{aligned}
$$

Where it is assumed that $Y_{t}^{\text {host }}, Y_{t}^{\text {home }}$ and $X_{t}^{\text {rem }}$ are stationary, $\varepsilon_{t}^{\text {host }}$ and $\varepsilon_{t}^{\text {home }}$ and $\varepsilon_{t}^{\text {rem }} \sim$ i.i. $d\left(0, \sigma_{\varepsilon i}^{2}\right)$ and $\operatorname{cov}\left(\varepsilon_{t}^{\text {host }}, \varepsilon_{t}^{\text {home }}, \varepsilon_{t}^{\text {rem }}\right)=0$

Using matrix algebra, we can write the system (Equ.1 to 3) in the compact form.

$$
\left[\begin{array}{ccc}
1 & a_{12} & a_{13} \\
a_{21} & 1 & a_{23} \\
a_{31} & a_{32} & 1
\end{array}\right]\left[\begin{array}{c}
Y_{t}^{\text {host }} \\
Y_{t}^{\text {home }} \\
X_{t}^{\text {rem }}
\end{array}\right]=\left[\begin{array}{c}
b_{10} \\
b_{20} \\
b_{30}
\end{array}\right]+\left[\begin{array}{lll}
b_{11} & b_{12} & b_{13} \\
b_{21} & b_{22} & b_{23} \\
b_{31} & b_{32} & b_{33}
\end{array}\right]\left[\begin{array}{c}
Y_{t-i}^{\text {host }} \\
Y_{t-i}^{\text {home }} \\
X_{t-i}^{\text {rem }}
\end{array}\right]+\left[\begin{array}{c}
\varepsilon_{t}^{\text {host }} \\
\varepsilon_{t}^{\text {home }} \\
\varepsilon_{t}^{\text {rem }}
\end{array}\right]
$$

Where $\mathrm{i}=1,2,3, \ldots, \mathrm{n}$

Simply, it can be expressed as follows.

$A Z_{t}=B_{0}+B_{1} Z_{t-i}+\varepsilon_{t}$

Where $Z_{t}$ is the $(\mathrm{n} * 1)$ vector of the endogenous variables, and $Z_{t-i}$ is the $\left(\mathrm{n}^{*} \mathrm{n}\right)$ matrix contains the lagged endogenous variables, and $\Sigma_{\varepsilon}=E\left(\varepsilon \varepsilon^{\prime}\right)$ gives the variance-covariance matrix of the structural innovations.

Pre-multiplying with $A^{-1}$, we obtained the corresponding reduced form $(\mathrm{VAR})^{6}$ in the context of SVAR given in Equation (5).

$A A^{-1} Z_{t}=B_{0} A^{-1}+B_{1} Z_{t-1} A^{-1}+\varepsilon_{t} A^{-1}$

Thus,

$$
Z_{t}=B_{0} A^{-1}+B_{1} Z_{t-1} A^{-1}+\varepsilon_{t} A^{-1}
$$

In other words the reduce form model given in Eq (5) is equal to

$Z_{t}=C_{0}+C_{1} X_{t-i}+e_{t}$

Where, $B_{0} A^{-1}=C_{0}, B_{1} A^{-1}=C_{1}$ and $\varepsilon_{t} A^{-1}=e_{t}$, the variance-covariance of the reduced form is given by $\Sigma_{e}=E\left(e e^{\prime}\right)$

Equation 7 can be written in matrix form as:

$$
\left[\begin{array}{c}
Y_{t}^{\text {host }} \\
Y_{t}^{\text {home }} \\
X_{t}^{\text {rem }}
\end{array}\right]=\left[\begin{array}{c}
c_{10} \\
c_{20} \\
c_{30}
\end{array}\right]+\left[\begin{array}{lll}
c_{11} & c_{12} & c_{13} \\
c_{21} & c_{22} & c_{23} \\
c_{31} & c_{32} & c_{33}
\end{array}\right]\left[\begin{array}{c}
Y_{t-i}^{\text {host }} \\
Y_{t-i}^{\text {home }} \\
X_{t-i}^{\text {rem }}
\end{array}\right]+\left[\begin{array}{c}
e_{1 t} \\
e_{2 t} \\
e_{3 t}
\end{array}\right]
$$

Equations (7) and (8) represent standard reduced form VAR which can be estimated with OLS. The predetermined variables are comprised on the right hand side of the equation, the error terms are white noise. The errors are serially uncorrelated but correlated across

\footnotetext{
${ }^{6}$ The main problem in the structural model estimation is that one cannot directly estimate the variables of interest such $A$ and $B_{1}$ in Eq. (5)
} 
equations. We can't use directly OLS to estimate SVAR, equation (5) due to contemporaneous effects correlated with the structural shocks $\left(\varepsilon_{t}\right)$.

Following the AB-model of Amisano and Gianini (1997)

$A e_{t}=B \varepsilon_{t} \Rightarrow e_{t}=A^{-1} B \varepsilon_{t}$

$\boldsymbol{A}$ gives the contemporaneous relationship between the variables while matrices $\boldsymbol{B}$ point out how the structural shocks affect the variables. In investigating the effect of an isolated shock, the structural shocks are assumed to be orthogonal.

The contemporaneous relationships among the variables tcan then be given by:

$$
\begin{aligned}
& e^{\text {host }}=\varepsilon^{\text {host }} \\
& e^{\text {home }}=a_{21} e^{\text {host }}+a_{23} e^{\text {rem }}+\varepsilon^{\text {home }} \\
& e^{\text {rem }}=a_{31} e^{\text {host }}+\varepsilon^{\text {rem }}
\end{aligned}
$$

Where $\mathrm{e}^{\text {host }} e^{\text {home }}, e^{\text {rem }}$ is the regression residual obtained from the reduced form VAR, and $\varepsilon^{\text {host }}, \varepsilon^{\text {home }}, \varepsilon^{\text {rem }}$ are the pure shocks (i.e., structural innovations) to the detrended series in terms of $\log ,\left(Y^{\text {host }}\right)\left(Y^{\text {home }}\right)$ and $\left(X^{\text {rem }}\right)$, respectively. Hence the above specified model presented in a reduced form provides the number of assumptions necessary to identify the structural VAR model. The assumptions imply that changes in the host output are assumed to be affected only by its own shocks, meaning that host output is not instantaneously affected by other variables in the model. Home output is only affected by shocks to host output and remittances, whereas remittances are influenced by host output shocks. The above specification is an appealing one as it does not impose any restrictions on the long-run behavior of economic variables and the number of restrictions matches the necessary number of restrictions to exactly identify a three variables SVAR model.

\section{Cross-Correlation Results:}

First, we look at cross-correlation between aggregate and country-wise remittances on the one hand and the corresponding annual GDP for home and host economies on the other.

\section{Remittances and Home Output}

The results given in table 2 show that remittances and South Asia's regional output taken as a whole do not appear to commove during the period from 1975 to 2011. However, countrywise correlations show a different picture: We find a negative and significant correlation between remittances and output for both Pakistan and Bangladesh. In case of Pakistan, the correlation is contemporaneous while for Bangladesh, the correlation appears with a lag of two years. On the other hand, the correlation between remittances and output is not significant in case of India and Sri Lanka. For India, the relationship appears to be negative, while for Sri Lanka, it has a positive sign. In other words, there is no systematic relationship between remittances and home GDP in either of the two countries meaning that migrants' decision about the amount to remit may in both cases be independent of any shock to the economy and may not play a major role in limiting the vulnerability to shocks. 
Table 2. Cross Correlation between Home GDP at time $t(t=1975, \ldots, 2011)$ and Real Remittances at $t+i$ and $t-i \quad(i=0,1,2)$

\begin{tabular}{l|lllllll}
\hline & & $\boldsymbol{t}-\mathbf{2}$ & $\boldsymbol{t}-\mathbf{1}$ & $\boldsymbol{t}$ & $\boldsymbol{t}+\boldsymbol{1}$ & $\boldsymbol{t + 2}$ & Co-movement and Phase Shift \\
\hline $\begin{array}{l}\text { Cross correlation } \\
\text { between Home }\end{array}$ & South Asia & -0.04 & 0.16 & -0.02 & -0.01 & 0.20 & Acyclical \\
GDP and & India & -0.05 & 0.10 & -0.01 & -0.10 & 0.24 & Acyclical \\
Remittances. & Pakistan & 0.28 & -0.10 & $\mathbf{- 0 . 3 3}$ & -0.26 & 0.08 & Counter-cyclical and coincident \\
& Bangladesh & $\mathbf{- 0 . 3 4}$ & 0.17 & -0.24 & 0.20 & 0.25 & $\begin{array}{l}\text { Counter-cyclical and leads } \\
\end{array}$ \\
& Sri Lanka & -0.29 & -0.13 & 0.18 & $\mathbf{0 . 3 1}$ & 0.19 & Acyclical \\
\hline
\end{tabular}

* Coefficient statistically significant at 5\% significance level

\section{Remittances and Host Output}

Remittances from South Asia as a whole appear to move acyclically with the GCC output during the examined period 1975-2011 (Table 3). Likewise, country-wise correlations are mostly acyclical. The association in case of Sri Lanka however, appears to be pro-cyclical. The FD filter shows an intriguing result for Pakistan, as remittance flows to the country appear to behave counter-cyclically to the GCC output. This last finding merits some discussion. In the 1970s and 1980s, Pakistan supplied a big proportion of the labour requirements of GCC countries. Official remittances to Pakistan during that period accounted for about half of the total flows to South Asia, and were as a result, most hit due to the 199091 Gulf war and the ensuing financial difficulties that the GCC countries faced. Thousands of Pakistani temporary migrants returned at that time, bringing with them all their savings. This reflects in the negative correlation between flows to Pakistan and the GCC output. Another explanation, which is also applicable to other South Asian countries to certain extent, is that during the current economic slump, remittances to Pakistan from GCC have not suffered, and have in fact kept on increasing, again indicating a negative correlation.

Table 3. Cross Correlation between Weighted GCC Output at time $t(t=1975, \ldots$ 2011) and Real Remittances at $t+i$ and $t-i(i=0,1,2)$

\begin{tabular}{l|lllllll}
\hline & & $\boldsymbol{t}-\mathbf{2}$ & $\boldsymbol{t}-\mathbf{1}$ & $\boldsymbol{t}$ & $\boldsymbol{t}+\mathbf{1}$ & $\boldsymbol{t}+\mathbf{2}$ & Co-movement and Phase Shift \\
\hline Cross correlation & South Asia & 0.06 & 0.07 & -0.04 & -0.06 & -0.17 & Acyclical \\
between GCC & India & 0.02 & 0.25 & 0.03 & -0.02 & -0.29 & Acyclical \\
output and & Pakistan & 0.30 & -0.06 & $\mathbf{- 0 . 4 5}$ & -0.31 & -0.14 & Counter-cyclical and coincident \\
Remittances. & Bangladesh & 0.06 & -0.19 & -0.04 & 0.25 & 0.09 & Acyclical \\
& Sri Lanka & -0.17 & $\mathbf{0 . 3 4}$ & $\mathbf{0 . 3 7}$ & $\mathbf{0 . 3 5}$ & -0.12 & Pro-cyclical and coincident \\
\hline
\end{tabular}

* Coefficient statistically significant at 5\% significance level

Table 4. Cross Correlation between Weighted North American Output at time $t(t=1975, \ldots$, 2011) and Real Remittances at $t+i$ and $t-i(i=0,1,2)$

\begin{tabular}{l|lllllll}
\hline & & $\boldsymbol{t}-\mathbf{2}$ & $\boldsymbol{t}-\mathbf{1}$ & $\boldsymbol{t}$ & $\boldsymbol{t + 1}$ & $\boldsymbol{t + 2}$ & Co-movement and Phase Shift \\
\hline $\begin{array}{l}\text { Cross correlation } \\
\text { between North }\end{array}$ & South Asia & -0.02 & 0.25 & $\mathbf{0 . 4 6}$ & $\mathbf{0 . 3 7}$ & 0.24 & Pro-cyclical and coincident \\
$\begin{array}{l}\text { American output } \\
\text { and Remittances. }\end{array}$ & India & -0.30 & 0.05 & 0.27 & $\mathbf{0 . 4 8}$ & $\mathbf{0 . 4 3}$ & $\begin{array}{l}\text { Pro-cyclical and lags output by } \\
\text { one year }\end{array}$ \\
& Pakistan & 0.29 & 0.29 & 0.16 & -0.05 & -0.13 & $\begin{array}{l}\text { Acyclical } \\
\end{array}$ \\
& Bangladesh & -0.01 & 0.30 & $\mathbf{0 . 3 6}$ & $\mathbf{0 . 3 6}$ & 0.17 & $\begin{array}{l}\text { Pro-cyclical and coincident } \\
\text { Sri Lanka }\end{array}$ \\
& -0.39 & -0.22 & -0.01 & $\mathbf{0 . 3 7}$ & $\mathbf{0 . 6 4}$ & $\begin{array}{l}\text { Pro-cyclical and lags output by } \\
\text { two year }\end{array}$ \\
\hline
\end{tabular}

* Coefficient statistically significant at 5\% significance level 
Both aggregate and country-wise remittances show a procyclical tendency with respect to the North American economic output (Table 4). However, the significance of this correlation disappears when the other two filters are used (results not shown). Among country-wise remittances, Pakistan seems to be an exception, as the correlation of remittances to North American GDP is found to be acyclical in the case of the country. Similar to the association with North American output, South Asian remittances appear to be contemporaneously and procyclically correlated with weighted European output (Table 5). This pro-cyclical behaviour is also evident on the country level except for remittances to Pakistan, which remain acyclical.

Table 5. Cross Correlation between Weighted European Output at time $t(t=1975, \ldots, 2011)$ and Real Remittances at $t+i$ and $t-i(i=0,1,2)$

\begin{tabular}{|c|c|c|c|c|c|c|c|}
\hline & & $t-2$ & $t-1$ & $t$ & $t+1$ & $t+2$ & Co-movement and Phase Shift \\
\hline \multirow{5}{*}{$\begin{array}{l}\text { Cross correlation } \\
\text { between European } \\
\text { output and } \\
\text { Remittances }\end{array}$} & South Asia & -0.02 & 0.14 & 0.40 & 0.28 & 0.09 & Pro-cyclical and coincident \\
\hline & India & -0.21 & 0.05 & 0.30 & 0.39 & 0.18 & $\begin{array}{l}\text { Pro-cyclical and lags output by } \\
\text { one year }\end{array}$ \\
\hline & Pakistan & 0.08 & -0.04 & -0.03 & -0.03 & -0.06 & Acyclical \\
\hline & Bangladesh & 0.17 & 0.18 & 0.27 & 0.34 & 0.05 & $\begin{array}{l}\text { Pro-cyclical and lags output by } \\
\text { one year }\end{array}$ \\
\hline & Sri Lanka & 0.01 & 0.00 & -0.12 & 0.13 & 0.34 & $\begin{array}{l}\text { Pro-cyclical and lags output by } \\
\text { two year }\end{array}$ \\
\hline
\end{tabular}

* Coefficient statistically significant at 5\% significance level

Table 6. Cross Correlation between Weighted Asia Pacific Output at time $t(t=1975, \ldots, 2011)$ and Real Remittances at $t+i$ and $t-i \quad(i=0,1,2)$

\begin{tabular}{l|lllllll}
\hline & & $\boldsymbol{t}-\mathbf{2}$ & $\boldsymbol{t}-\mathbf{1}$ & $\boldsymbol{t}$ & $\boldsymbol{t}+\boldsymbol{1}$ & $\boldsymbol{t}+\mathbf{2}$ & Co-movement and Phase Shift \\
\hline $\begin{array}{l}\text { Cross correlation } \\
\text { between Asia }\end{array}$ & South Asia & 0.23 & 0.30 & $\mathbf{0 . 3 7}$ & 0.19 & -0.20 & Pro-cyclical and coincident \\
$\begin{array}{l}\text { Pacific Output } \\
\text { and Remittances }\end{array}$ & India & 0.14 & 0.32 & $\mathbf{0 . 4 3}$ & 0.34 & -0.21 & Pro-cyclical and coincident \\
& Pakistan & $\mathbf{0 . 4 2}$ & 0.11 & -0.06 & -0.17 & -0.25 & Pro-cyclical and leads output \\
& Bangladesh & $\mathbf{0 . 3 1}$ & 0.19 & 0.27 & 0.23 & 0.02 & Ay two year \\
& Sri Lanka & 0.05 & $\mathbf{0 . 3 4}$ & $\mathbf{0 . 4 1}$ & $\mathbf{0 . 3 8}$ & 0.021 & Pro-cyclical and coincident \\
\hline
\end{tabular}

* Coefficient statistically significant at $5 \%$ significance level

Remittances to the region appear to be procyclically correlated with the weighted aggregate output for the countries in the Asia and Pacific region (Table 6). This behaviour is also evident in the case of India and Sri Lanka, while remittances to Pakistan and Bangladesh seem to be acyclical.

\section{Home and Host output:}

Tables 7 to 10 show cross correlations between the annual outputs of South Asia and the four host regions. Similar to remittance flows, South Asian output does not appear to be significantly correlated with the GCC regional output. The annual GDP of South Asian countries is likewise acyclical, except for the Pakistani GDP which shows procyclical behaviour. The latter is understandable considering the fact that remittances to Pakistan are countercyclical both with respect to Pakistan's and GCC's regional output. Pro-cyclicality is also observed in the case of Sri Lankan GDP.

For the group of South Asian countries taken as a whole, the weighted annual regional output is found to be acyclical to the North American output. On the country level, the annual output of India, the regional economic behemoth, also reflects this lack of significant correlation. The two smaller economies, Bangladesh and Sri Lanka, however show a pro-cyclical behaviour. The lack of a clear relationship on the regional level is in spite of the fact that the 
United States are among the region's major trade partners and an important source of investment flows.

Table 7. Cross Correlation between Weighted GCC Output at time $t(t=1975, \ldots, 2011)$ and Home GDP at $\mathrm{t}+\mathrm{i}$ and $\mathrm{t}-\mathrm{i}(\mathrm{i}=0,1,2)$

\begin{tabular}{l|lllllll}
\hline & & $\boldsymbol{t}-\mathbf{2}$ & $\boldsymbol{t}-\mathbf{1}$ & $\boldsymbol{t}$ & $\boldsymbol{T + 1}$ & $\boldsymbol{t + 2}$ & Co-movement and Phase Shift \\
\hline Cross correlation & South Asia & 0.11 & 0.08 & 0.04 & 0.15 & 0.07 & Acyclical \\
between GCC and & India & 0.13 & 0.05 & -0.00 & 0.14 & 0.08 & Acyclical \\
Home output & Pakistan & -0.12 & 0.27 & $\mathbf{0 . 4 0}$ & $\mathbf{0 . 3 8}$ & -0.09 & Pro-cyclical and coincident \\
& Bangladesh & 0.13 & 0.10 & -0.09 & -0.29 & 0.07 & Acyclical \\
& Sri Lanka & -0.12 & 0.32 & $\mathbf{0 . 3 8}$ & -0.09 & -0.05 & Pro-cyclical and coincident \\
\hline
\end{tabular}

* Coefficient statistically significant at 5\% significance level

Table 8. Cross Correlation between Weighted North American Output at time $t(t=1975, \ldots$, 2011) and Home GDP at $t+i$ and $t-i(i=0,1,2)$

\begin{tabular}{|c|c|c|c|c|c|c|c|}
\hline & & $t-2$ & $t-1$ & $t$ & $t+1$ & $t+2$ & Co-movement and Phase Shift \\
\hline \multirow{5}{*}{$\begin{array}{l}\text { Cross correlation } \\
\text { between North } \\
\text { American and } \\
\text { Home output }\end{array}$} & South Asia & -0.07 & 0.32 & 0.29 & -0.02 & -0.14 & $\begin{array}{l}\text { Pro-cyclical and leads output } \\
\text { by one year }\end{array}$ \\
\hline & India & -0.05 & 0.32 & 0.24 & -0.06 & -0.17 & $\begin{array}{l}\text { Pro-cyclical and leads output } \\
\text { by one year }\end{array}$ \\
\hline & Pakistan & -0.22 & 0.17 & 0.34 & 0.25 & $\mathbf{0 . 3 3}$ & Pro-cyclical and coincident \\
\hline & Bangladesh & 0.05 & 0.17 & 0.49 & 0.24 & -0.09 & Pro-cyclical and coincident \\
\hline & Sri Lanka & -0.12 & 0.08 & 0.33 & 0.24 & -0.11 & Pro-cyclical and coincident \\
\hline
\end{tabular}

* Coefficient statistically significant at $5 \%$ significance level

Table 9. Cross Correlation between Weighted European Output at time $t(t=1975, \ldots, 2011)$ and Home GDP at $t+i$ and $t-i \quad(i=0,1,2)$

\begin{tabular}{l|lllllll}
\hline & & $\boldsymbol{t}-\mathbf{2}$ & $\boldsymbol{t}-\mathbf{1}$ & $\boldsymbol{t}$ & $\boldsymbol{t}+\mathbf{1}$ & $\boldsymbol{t}+\mathbf{2}$ & Co-movement and Phase Shift \\
\hline $\begin{array}{l}\text { Cross correlation } \\
\text { between European } \\
\text { and Home output }\end{array}$ & South Asia & 0.29 & 0.65 & 0.18 & -0.20 & -0.40 & $\begin{array}{l}\text { Pro-cyclical and leads output } \\
\text { by one year }\end{array}$ \\
& India & 0.30 & $\mathbf{0 . 6 2}$ & 0.14 & -0.21 & -0.40 & $\begin{array}{l}\text { Pro-cyclical and leads output } \\
\text { by one year }\end{array}$ \\
& $\begin{array}{llllll}\text { Pakistan } \\
\text { Bangladesh }\end{array}$ & -0.18 & $\mathbf{0 . 4 8}$ & $\mathbf{0 . 3 2}$ & 0.03 & -0.09 & $\begin{array}{l}\text { Pro-cyclical and leads output } \\
\text { by one year }\end{array}$ \\
& Sri Lanka & 0.01 & 0.25 & 0.30 & -0.02 & -0.21 & $\begin{array}{l}\text { Acyclical } \\
\text { Aco-cyclical and coincident }\end{array}$ \\
\hline
\end{tabular}

* Coefficient statistically significant at 5\% significance level

Table 10. Cross Correlation between Weighted Asia Pacific Output at time $t(t=1975, \ldots, 2011)$ and Home GDP at $t+i$ and $t-i \quad(i=0,1,2)$

\begin{tabular}{|c|c|c|c|c|c|c|c|}
\hline & & $t-2$ & $t-1$ & $t$ & $t+1$ & $t+2$ & Co-movement and Phase Shift \\
\hline \multirow{5}{*}{$\begin{array}{l}\text { Cross correlation } \\
\text { between Asia } \\
\text { Pacific and } \\
\text { Home output }\end{array}$} & South Asia & -0.08 & 0.37 & 0.28 & 0.17 & -0.04 & $\begin{array}{l}\text { Pro-cyclical and leads output } \\
\text { by one year }\end{array}$ \\
\hline & India & -0.08 & 0.34 & 0.25 & 0.17 & -0.04 & $\begin{array}{l}\text { Pro-cyclical and leads output } \\
\text { by one year }\end{array}$ \\
\hline & Pakistan & -0.06 & 0.45 & 0.47 & 0.37 & 0.05 & Pro-cyclical and coincident \\
\hline & Bangladesh & 0.17 & 0.12 & -0.14 & -0.28 & -0.09 & Acyclical \\
\hline & Sri Lanka & 0.05 & 0.08 & 0.22 & -0.10 & -0.21 & Acyclical \\
\hline
\end{tabular}

* Coefficient statistically significant at $5 \%$ significance level

Likewise, the correlation between the South Asian and European aggregate output is found to be insignificant. On the country level as well, the outputs do not seem to be correlated except for Bangladeshi output, which is found to be pro-cyclical. 
The aggregate South Asian output does not appear to commove with Asia Pacific region's aggregate output either. This acyclical behaviour is also evident in case of Indian and Bangladeshi annual output.

From the above results, we can see that remittances to South Asian countries are usually procyclical with respect to the economies of host regions, and acyclical with respect to home economies. However, remittances to two countries Pakistan and Bangladesh present a different behaviour. Remittances to the two countries move countercyclically with their home economies, while those to Pakistan are often acyclical with respect to host economies. The acyclical behaviour of remittances with respect to the regional output can be attributed mainly to the size and significance of Indian economy in the region. The latter constitutes about 80 percent of the regional output, and remittances to India, at 3 percent of the GDP during the studied period, form a small proportion of the total foreign financial inflows to the country.

With these results, we have an idea of how remittances have acted on the macroeconomic level. However, these results only give us an idea on the correlation between remittances and home and host output. In the next section, we examine remittances' causal links with the macro economy.

\section{Results of Structure VAR models:}

Before estimating our SVAR models, we conduct various diagnostic tests to check the stability and adequacy of the models. The stability test reports the inverse root of the characteristics AR polynomials. If all roots have modulus less than one and lie inside VAR, then the estimated VAR is considered stable. All the specifications of our SVAR model are found to be stable. We also conduct the autocorrelation LM test and Normality test to check for autocorrelation of residuals and normality.

\subsection{Impulse Response Functions}

Impulse responses are commonly used in structural vector autoregressive (SVAR) analysis in order to assess the responses of the variables to exogenous shocks. They provide a convenient summary of the inferences for a large number of estimated coefficients in the Structural VAR. The impulse response function traces the effect of a one-time shock to one of the innovations on current and future values of endogenous variables. In order to calculate the impulse response functions and variance decompositions, the innovations are orthogonalized by a structural decomposition following Sims and Bernanke (1986). In addition, standard-error bands of two standard deviations representing the statistical significance of the responses are obtained, shown by the dotted lines. An optimal lag length of two is chosen based on various information criteria in order to obtain reasonable dynamics without excessive loss of degrees of freedom. We utilize impulse response function to examine the dynamic causal relationship between Remittances, host and home output.

\section{Shock to GCC output:}

The impulse responses of remittances to the four South Asian countries to a shock to the GCC economy are given in figure 1 . The impulse response of remittances to India and Bangladesh to the GCC output remains insignificant. The reaction of remittances to Pakistan to the innovation in GCC output, however, looks negative and significant. This is in line with a significantly negative correlation found for remittances to Pakistan described above. In contrast to the responses of remittances to the other three countries to changes in GCC output, remittances to Sri Lanka react immediately and positively to GCC output, corroborating the positive correlation found above.

The response of the home output to a shock to the GCC economy is similarly different among the four home economies: from a positive but mostly insignificant one for the Bangladeshi 
GDP, to a consistently insignificant one for the Indian GDP, to a significantly positive one for the Sri Lankan GDP. The response of the cyclical component of Pakistan's output to the shock to the GCC output is positive and significant in second period.

Figure 1. Impulse Response Functions: GCC Output

Response to Structural One S.D. Innovations \pm 2 S.E.
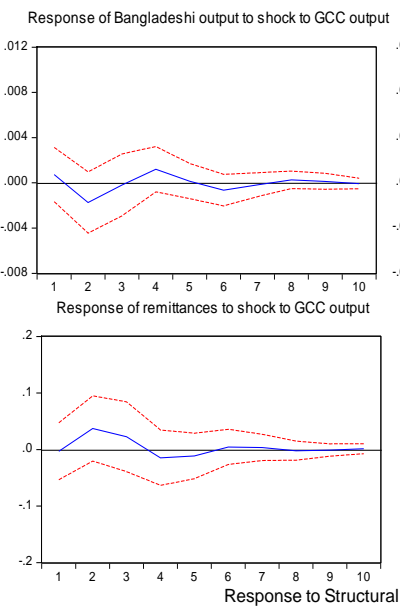

Response of Pakistani output to shock to GCC outpu

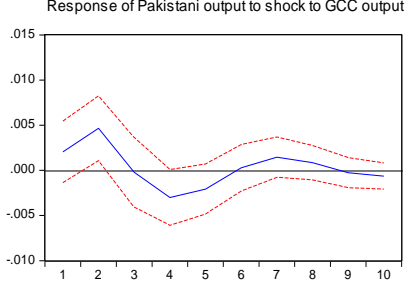

Response of remittances to shock to GCC output

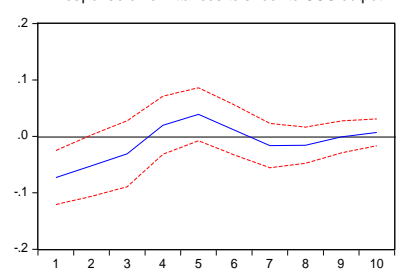

Response to Structural One S.D. Innovations \pm 2 S.E.

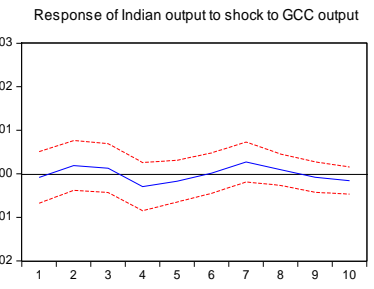

Response of remittances to shock to GCC output
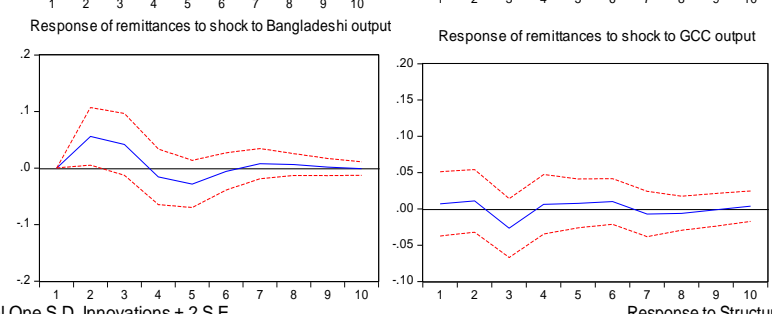

Response to Structura

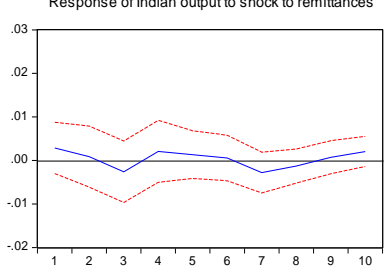

Response of remittances to shock to Indian output
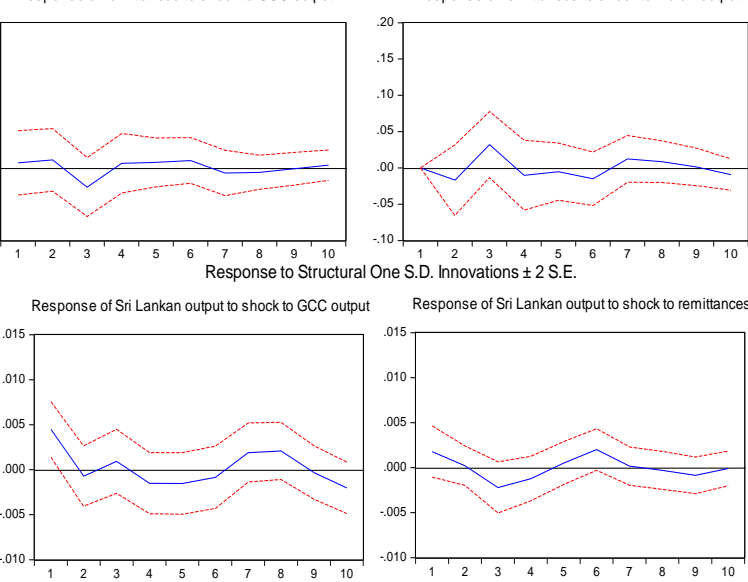

Response of Sri Lankan output to shock to remittances
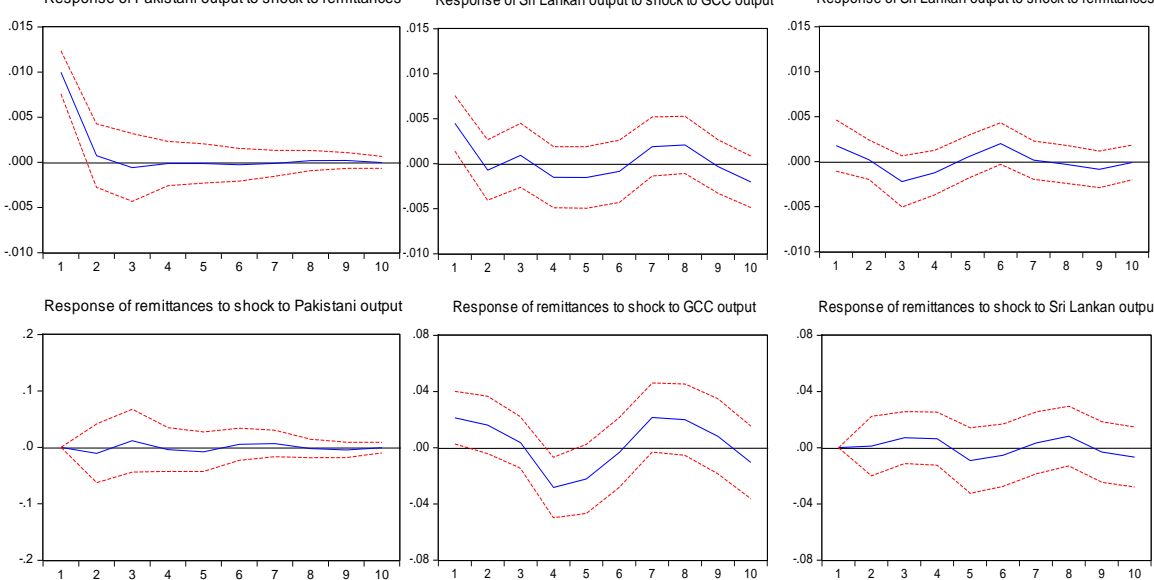

Figure 2. Impulse Response Functions: North American Output

Response to Structural One S.D. Innovations \pm 2 S.E.

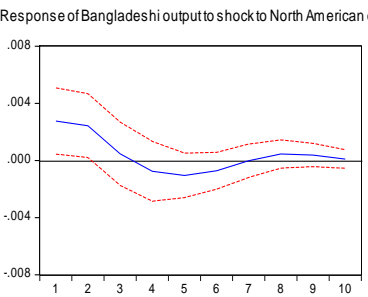

Response of remittances to shock to North American output

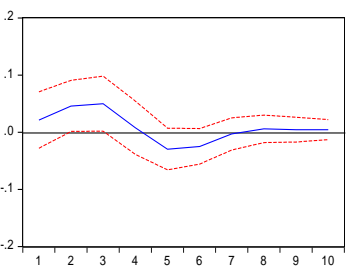

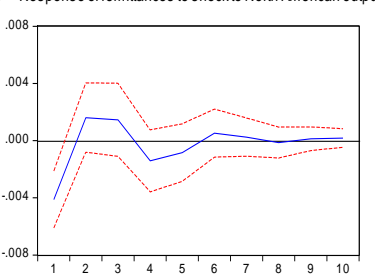

Response ofremittances to shock to Bangladeshioutput

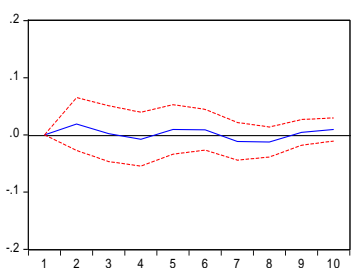

Response to Structural One S.D. Innovations \pm 2 S.E.

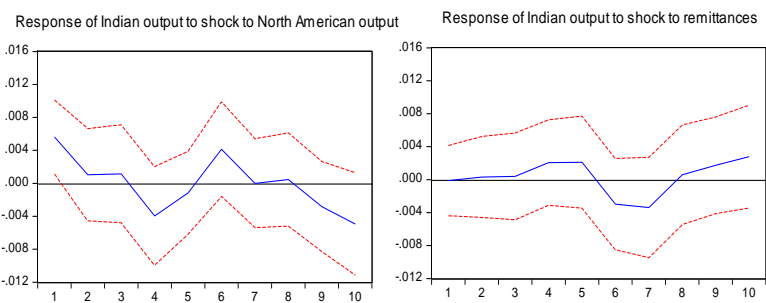

Response of remittances to shock to North American output Response of remittances to shock to Indian output
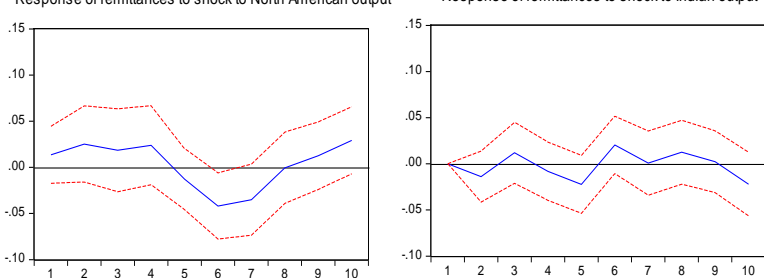

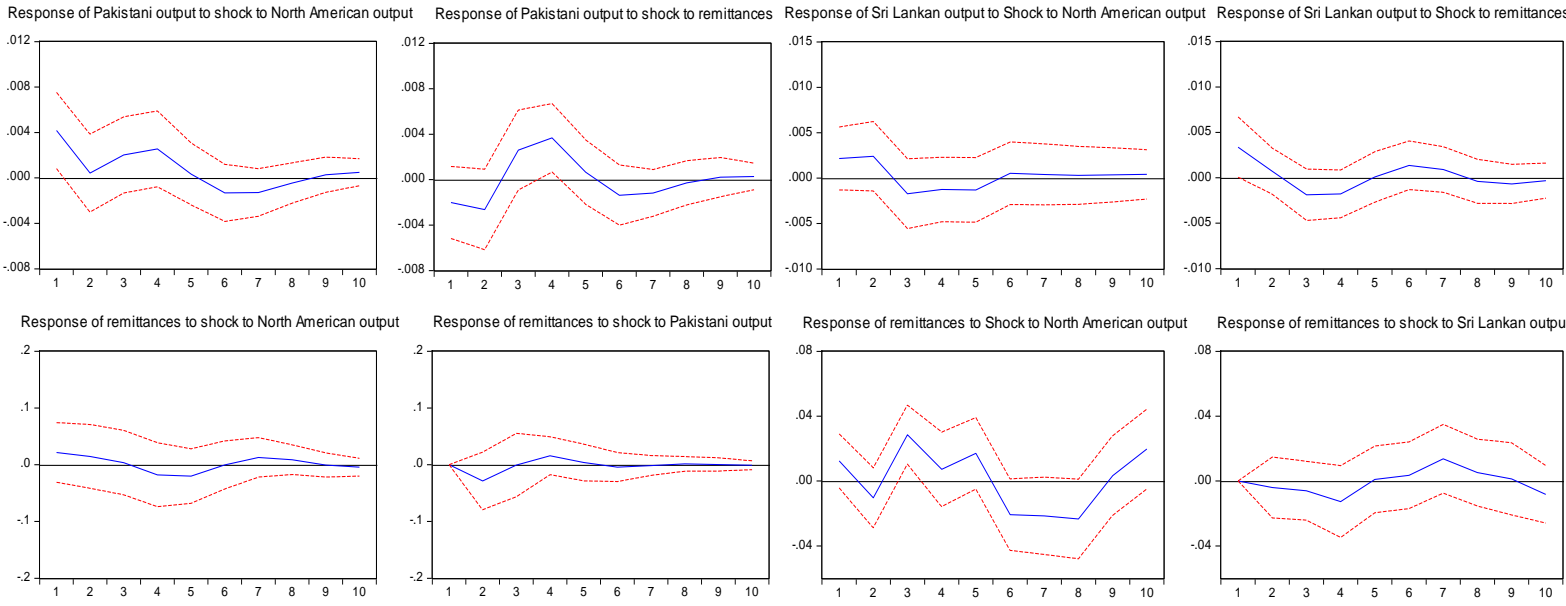

\section{Shock to North American output:}

Figure 2 presents impulse responses to a shock to North American output. Remittances to the two smaller countries respond pro-cyclically to North American output. The positive response of Bangladeshi output is statistically significant for the second and third year after the shock, while for Sri Lanka, the positive response appears after three years. The response of remittances to both India and Pakistan seems trivial.

As regards the response of home output, both India and Pakistan show an instantaneous positive association with the North American output. This point to the fact that both the Indian and Pakistani business cycles are to some degree synchronized with the North American cycle, and therefore, shocks to North American output do affect the GDP of the two main South Asian countries. Similarly, in case of Bangladesh, the response of the GDP is positive and lasts two years, while for Sri Lanka no significant relationship is found.

\section{Shock to European output:}

Remittances to the region coming from Europe, just as for those from North America, respond to innovations in the host output in two distinct ways (figure 3). As seen with other regions, here too we see a dichotomy of reactions between the region's larger and smaller economies. Those to India and Pakistan do not significantly vary with European output, while remittances to Bangladesh and Sri Lanka increase in response to a shock to the host economy, even though with a lag of one year. The response of home economies to innovations in the European output is generally insignificant, except for Sri Lanka whose output shows a contemporaneous increase in response to a shock to the European output.

\section{Figure 3. Impulse Response Functions: European Output}
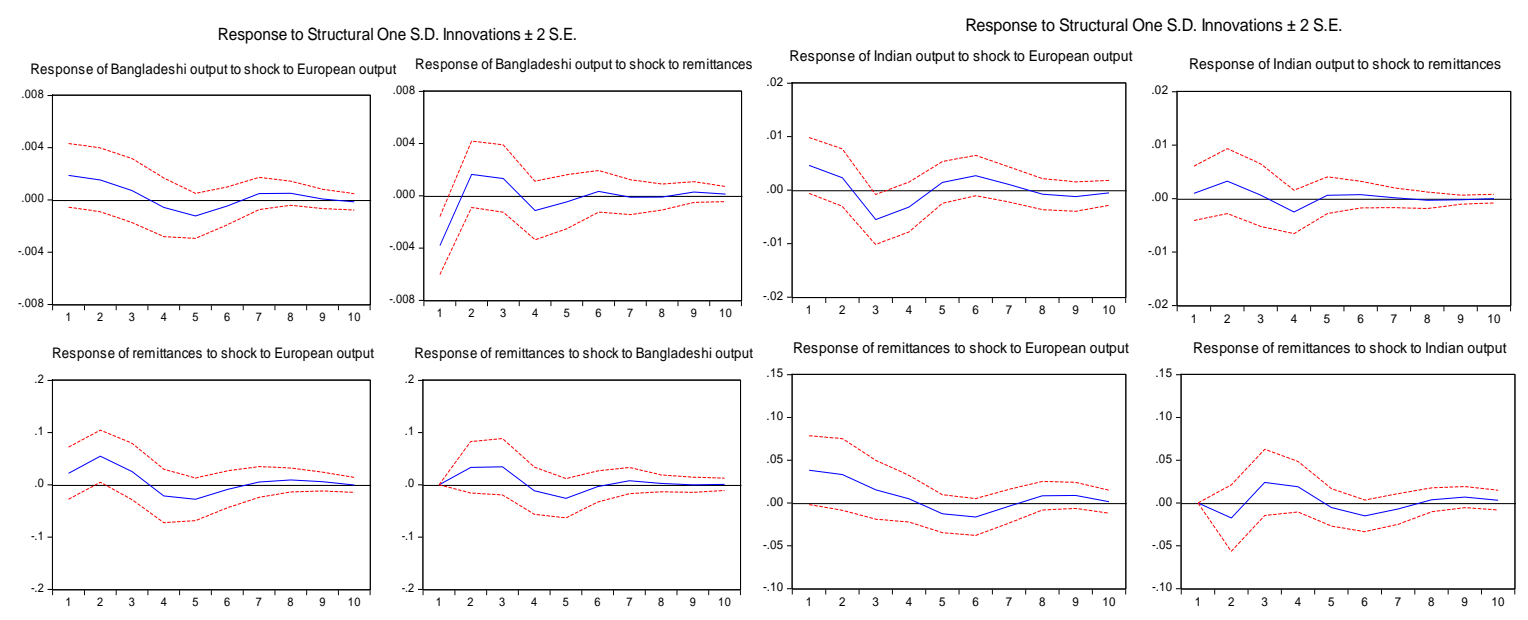
Response to Structural One S.D. Innovations \pm 2 S.E.

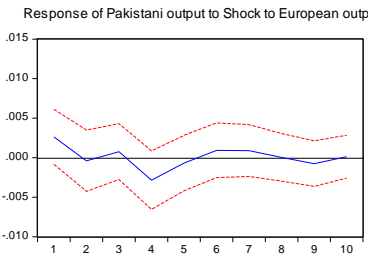

Response of remittances to Shock to European outpu

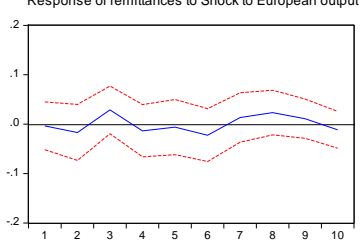

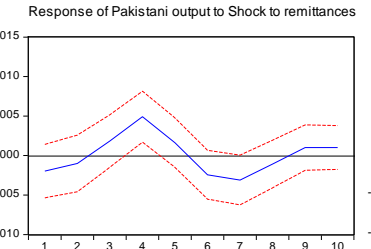

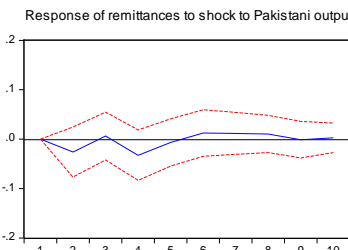

Response to Structural One S.D. Innovations \pm 2 S.E.

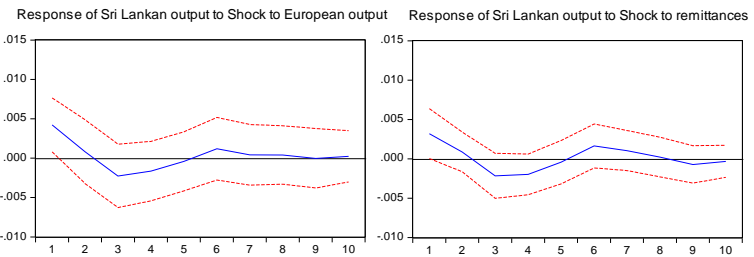

Response of remittances to Shock to European outpu
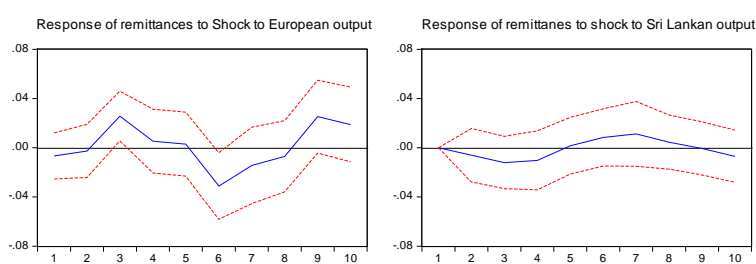

Figure 4. Impulse Response Functions: Asia Pacific Output

Response to Structural One S.D. Innovations \pm 2 S.E.

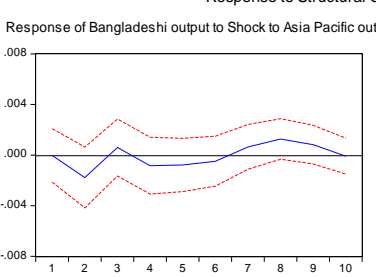

Response of remittances to Shock to Asia Pacific outpu

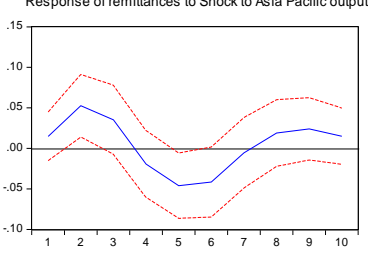

Response to Structural One S.D. Innovations \pm 2 S.E.

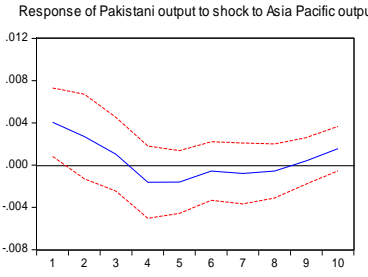

Response of remittances to shock to Asia Pacific outpu

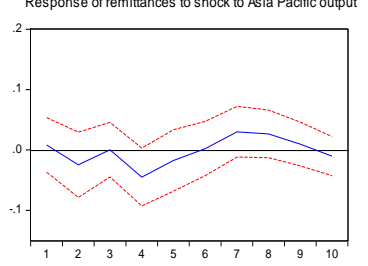

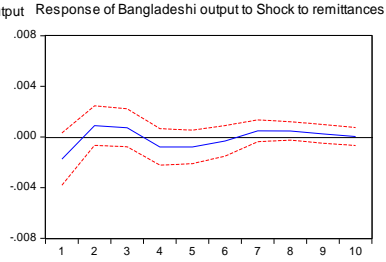
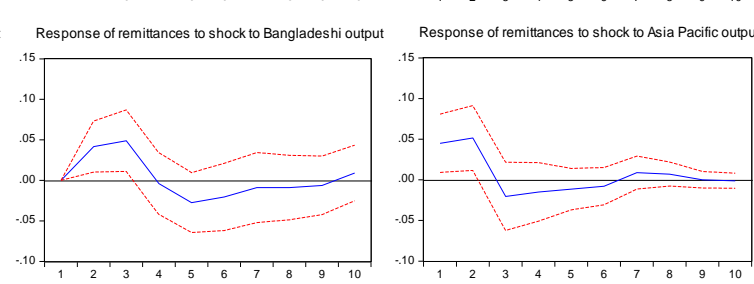

Response to Structural One S.D. Innovations \pm 2 S. E.
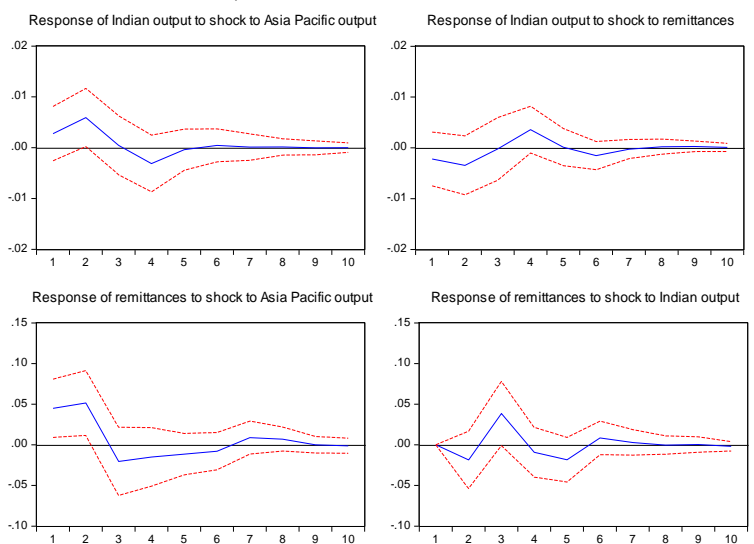

Response to Structural One S.D. Innovations \pm 2 S.E.
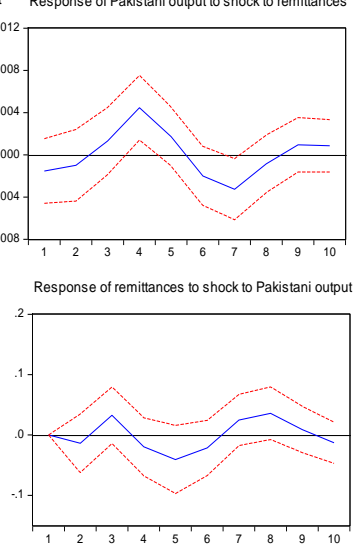

Response of Sri Lankan output to shock to Asia Pacific output Response of Sri Lankan output to shock to remittances

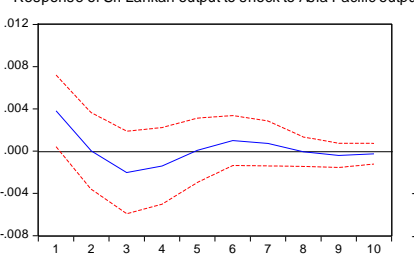

Response of remittances to shock to Asia Pacific outp

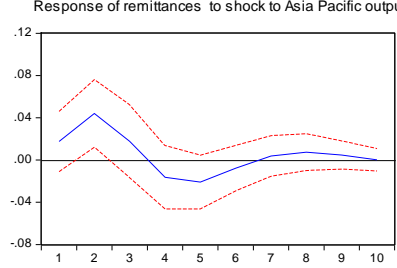

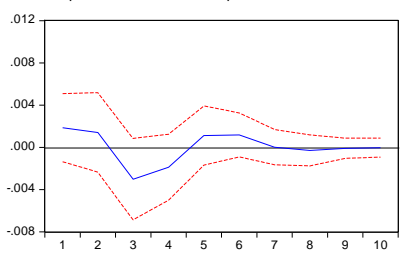

Response of remittances to shock to Sri Lankan output

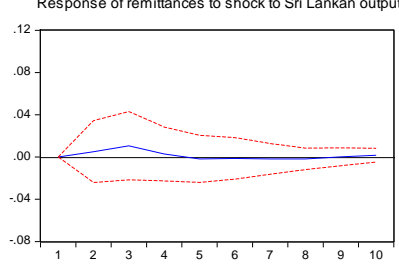

\section{Shock to Asia Pacific regional output:}

The responses of remittances to South Asian countries and their GDP to shocks to economies of the Asia Pacific region are illustrated in Figure 4. Remittances to Pakistan show no significant impulse response to innovations in Asia Pacific economies. This may owe to the low share of remittances from the region in total remittance flows to the country. Remittances to India, Bangladesh and Sri Lanka, on the other hand, react positively to shocks to Asia Pacific region's output, though the impact is temporary. This finding can be explained in light of the fact that unlike Pakistan, the other three South Asian countries lie geographically closer 
to East Asia, and have significant migrant communities in countries such as Malaysia and Singapore.

\section{Shock to home economy:}

As seen in figures 1 to 4 , the response of remittance flows to shocks to home economy output is different than that on the host economies, as the four countries all show their domestic economy specificities. For instance, remittances to Bangladesh show a positive association with the Bangladesh GDP. Remittances to the country respond positively to a shock to the home economy, but the impact dissipates within a few years.

In contrast, Indian remittances seem to react contemporaneously and negatively to shocks to home output. Likewise, the response of remittances to Pakistan to change in the country's output is mostly negative and temporary. Remittances to Pakistan, therefore, reflect an overall counter-cyclical behaviour with respect to the home economy.

Different from the other three countries, remittance flows to Sri Lanka show a mixed behaviour; with remittances to the country from GCC and Asia Pacific showing an immediate positive response, and North America and Europe showing a contemporaneous negative impact.

\subsection{Variance Decompositions Analysis:}

Next, we obtain forecast error variance decompositions corresponding to our SVAR models. These show the extent to which unanticipated changes in a variable are explained by a shock in the system. The higher the share of the variable in the error variance, the more important is the variable in the system. For calculating the error variance decomposition, we employ Sim and Bernanke Decomposition. Variance decomposition of five future periods is reported.

Tables 11 through 14 present the portion of the forecast error variance in the cyclical component of remittances. We find that remittances to the region are mostly affected by host output fluctuations rather than home output. For instance, between 3 and 35 percent of variance in remittances to Bangladesh is due to Asia Pacific region's output, while the proportion of remittance variance explained by Bangladesh's output ranges between 0 and 25 percent. Similarly, the output of Gulf countries accounts for between 23 and 31 percent of variance in remittances to Pakistan. The corresponding share for the home economy is a minor $0-11$ percent. The role of host economy fluctuations seems to be even more important in case of Sri Lanka, with output of Gulf countries (14 - 33 percent), North America (6 - 30 percent) and Asia Pacific region (4 - 30 percent) explaining the bulk of variance in remittances to the country.

Table 11. Error Variance Decomposition: Bangladesh

A. Percentage of variation in Bangladeshi output explained by remittances and regional outputs.

\begin{tabular}{l|llllllll}
\hline Horizon & $\begin{array}{l}\text { North } \\
\text { America }\end{array}$ & Rem & GCC & Rem & Europe & Rem & $\begin{array}{l}\text { Asia } \\
\text { Pacific }\end{array}$ & Rem \\
\hline $\mathbf{1}$ & 15.0 & 33.4 & 1.05 & 15.2 & 6.54 & 26.8 & 0.00 & 8.10 \\
$\mathbf{2}$ & 22.6 & 32.7 & 5.97 & 18.1 & 9.63 & 28.2 & 7.48 & 9.14 \\
$\mathbf{3}$ & 21.4 & 33.7 & 5.83 & 18.6 & 9.68 & 28.7 & 7.57 & 9.45 \\
$\mathbf{4}$ & 21.4 & 35.4 & 7.54 & 21.4 & 9.87 & 29.7 & 8.22 & 9.74 \\
$\mathbf{5}$ & 22.4 & 35.3 & 7.45 & 22.1 & 11.8 & 29.2 & 9.06 & 10.54 \\
\hline
\end{tabular}


B. Percentage of variation in remittances to Bangladesh explained by home and host output

\begin{tabular}{l|llllllll}
\hline Horizon & $\begin{array}{l}\text { North } \\
\text { America } \\
\text { n Output }\end{array}$ & $\begin{array}{l}\text { Bangladeshi } \\
\text { Output }\end{array}$ & $\begin{array}{l}\text { GCC } \\
\text { Output }\end{array}$ & $\begin{array}{l}\text { Bangladeshi } \\
\text { Output }\end{array}$ & $\begin{array}{l}\text { Europe } \\
\text { an } \\
\text { Output }\end{array}$ & $\begin{array}{l}\text { Bangladesh } \\
\text { i Output }\end{array}$ & $\begin{array}{l}\text { Asia } \\
\text { Pacific } \\
\text { Output }\end{array}$ & $\begin{array}{l}\text { Bangladeshi } \\
\text { Output }\end{array}$ \\
\hline $\mathbf{1}$ & 2.10 & 0.00 & 0.05 & 0.00 & 2.23 & 0.00 & 2.83 & 0.00 \\
$\mathbf{2}$ & 10.6 & 1.49 & 5.11 & 11.5 & 13.2 & 4.22 & 24.0 & 14.0 \\
$\mathbf{3}$ & 16.9 & 1.22 & 5.98 & 15.3 & 13.5 & 7.55 & 26.0 & 25.4 \\
$\mathbf{4}$ & 17.0 & 1.41 & 6.51 & 15.8 & 14.7 & 7.81 & 27.5 & 24.8 \\
$\mathbf{5}$ & 19.1 & 1.64 & 6.71 & 17.7 & 16.4 & 9.49 & 34.30 & 25.0 \\
\hline
\end{tabular}

Table 12. Error Variance Decomposition: India

A. Percentage of variation in Indian output explained by remittances and regional outputs.

\begin{tabular}{l|llllllll}
\hline Horizon & $\begin{array}{l}\text { North } \\
\text { America }\end{array}$ & Rem & GCC & Rem & Europe & Rem & $\begin{array}{l}\text { Asia } \\
\text { Pacific }\end{array}$ & Rem \\
\hline $\mathbf{1}$ & 17.4 & 0.01 & 0.23 & 2.76 & 8.59 & 0.38 & 3.01 & 1.88 \\
$\mathbf{2}$ & 17.5 & 0.06 & 1.41 & 2.96 & 10.04 & 4.36 & 14.2 & 5.55 \\
$\mathbf{3}$ & 14.9 & 0.11 & 1.72 & 4.57 & 17.8 & 3.75 & 12.6 & 4.93 \\
$\mathbf{4}$ & 19.9 & 1.81 & 3.96 & 5.42 & 19.5 & 5.33 & 14.5 & 8.15 \\
$\mathbf{5}$ & 19.3 & 3.40 & 4.68 & 5.81 & 19.9 & 5.40 & 14.5 & 8.12 \\
\hline
\end{tabular}

B. Percentage of variation in remittances to India explained by home and host output

\begin{tabular}{l|llllllll}
\hline Horizon & $\begin{array}{l}\text { North } \\
\text { American } \\
\text { Output }\end{array}$ & $\begin{array}{l}\text { Indian } \\
\text { Output }\end{array}$ & $\begin{array}{l}\text { GCC } \\
\text { Output }\end{array}$ & $\begin{array}{l}\text { Indian } \\
\text { Output }\end{array}$ & $\begin{array}{l}\text { Europea } \\
\text { n Output }\end{array}$ & $\begin{array}{l}\text { Indian } \\
\text { Output }\end{array}$ & $\begin{array}{l}\text { Asia } \\
\text { Pacific } \\
\text { output }\end{array}$ & $\begin{array}{l}\text { Indian } \\
\text { Output }\end{array}$ \\
\hline $\mathbf{1}$ & 2.30 & 0.00 & 0.29 & 0.00 & 9.90 & 0.00 & 16.5 & 0.00 \\
$\mathbf{2}$ & 7.38 & 1.73 & 0.97 & 1.65 & 15.7 & 1.87 & 30.5 & 2.24 \\
$\mathbf{3}$ & 10.0 & 2.89 & 4.58 & 6.93 & 16.3 & 5.14 & 29.3 & 10.5 \\
$\mathbf{4}$ & 13.9 & 3.24 & 4.49 & 7.00 & 16.0 & 7.04 & 30.0 & 10.8 \\
$\mathbf{5}$ & 14.5 & 6.86 & 4.73 & 7.08 & 16.7 & 7.11 & 29.6 & 12.2 \\
\hline
\end{tabular}

Table 13. Error Variance Decomposition: Pakistan

A. Percentage of variation in Pakistani output explained by remittances and regional outputs.

\begin{tabular}{l|llllllll}
\hline Horizon & $\begin{array}{l}\text { North } \\
\text { America }\end{array}$ & Rem & GCC & Rem & Europe & Rem & $\begin{array}{l}\text { Asia } \\
\text { Pacific }\end{array}$ & Rem \\
\hline 1 & 16.2 & 3.79 & 4.04 & 0.04 & 6.55 & 3.67 & 16.9 & 2.44 \\
2 & 15.3 & 9.56 & 20.5 & 0.23 & 6.61 & 4.56 & 21.8 & 3.07 \\
3 & 16.7 & 13.7 & 18.9 & 7.85 & 6.86 & 7.41 & 22.1 & 4.51 \\
4 & 18.80 & 20.8 & 23.0 & 10.7 & 10.9 & 22.3 & 20.4 & 18.5 \\
5 & 18.80 & 21.0 & 25.1 & 10.7 & 10.9 & 23.3 & 21.1 & 19.7 \\
\hline
\end{tabular}

B. Percentage of variation in remittances to Pakistan explained by home and host output

\begin{tabular}{l|llllllll}
\hline Horizon & $\begin{array}{l}\text { North } \\
\text { American } \\
\text { Output }\end{array}$ & $\begin{array}{l}\text { Pakistan } \\
\text { i Output }\end{array}$ & $\begin{array}{l}\text { GCC } \\
\text { Output }\end{array}$ & $\begin{array}{l}\text { Pakistani } \\
\text { Output }\end{array}$ & $\begin{array}{l}\text { Europea } \\
\text { n } \\
\text { Output }\end{array}$ & $\begin{array}{l}\text { Pakistan } \\
\text { i Output }\end{array}$ & $\begin{array}{l}\text { Asia } \\
\text { Pacific } \\
\text { output }\end{array}$ & $\begin{array}{l}\text { Pakistani } \\
\text { Output }\end{array}$ \\
\hline 1 & 1.90 & 0.00 & 23.5 & 0.00 & 0.06 & 0.00 & 0.40 & 0.00 \\
2 & 2.21 & 2.67 & 28.9 & 0.40 & 1.27 & 2.88 & 3.43 & 0.94 \\
3 & 2.18 & 2.60 & 28.9 & 0.87 & 4.48 & 2.85 & 3.15 & 5.84 \\
4 & 2.87 & 3.04 & 27.5 & 0.79 & 4.23 & 5.74 & 9.73 & 5.93 \\
5 & 3.93 & 3.02 & 30.6 & 0.92 & 4.20 & 5.71 & 9.87 & 10.9 \\
\hline
\end{tabular}

Table 14. Error Variance Decomposition: Sri Lanka

A. Percentage of variation in Sri Lankan output explained by remittances and regional outputs.

\begin{tabular}{l|llllllll}
\hline Horizon & $\begin{array}{l}\text { North } \\
\text { America }\end{array}$ & Rem & GCC & Rem & Europe & Rem & $\begin{array}{l}\text { Asia } \\
\text { Pacific }\end{array}$ & Rem \\
\hline $\mathbf{1}$ & 4.50 & 10.9 & 22.2 & 3.51 & 16.4 & 9.39 & 13.5 & 3.20 \\
\hline
\end{tabular}




\begin{tabular}{l|llllllll}
\hline $\mathbf{2}$ & 9.40 & 10.7 & 22.6 & 3.54 & 16.7 & 9.87 & 13.0 & 4.83 \\
$\mathbf{3}$ & 9.99 & 11.5 & 17.7 & 6.64 & 17.4 & 11.6 & 13.4 & 10.4 \\
$\mathbf{4}$ & 10.3 & 12.7 & 18.1 & 7.27 & 17.7 & 13.2 & 14.1 & 12.4 \\
$\mathbf{5}$ & 11.0 & 12.24 & 18.9 & 7.11 & 17.2 & 12.9 & 13.9 & 13.0 \\
\hline
\end{tabular}

B. Percentage of variation in remittances to Sri Lanka explained by home and host output

\begin{tabular}{l|llllllll}
\hline Horizon & $\begin{array}{l}\text { North } \\
\text { America } \\
\text { Output }\end{array}$ & $\begin{array}{l}\text { Output } \\
\text { Sri }\end{array}$ & $\begin{array}{l}\text { Lanka } \\
\text { Output }\end{array}$ & $\begin{array}{l}\text { Output } \\
\text { Sri Lanka }\end{array}$ & $\begin{array}{l}\text { EuropeO } \\
\text { utput }\end{array}$ & $\begin{array}{l}\text { Output } \\
\text { Sri } \\
\text { Lanka }\end{array}$ & $\begin{array}{l}\text { Pacific } \\
\text { Asia } \\
\text { output }\end{array}$ & $\begin{array}{l}\text { Output Sri } \\
\text { Lanka }\end{array}$ \\
\hline $\mathbf{1}$ & 6.40 & 0.00 & 14.2 & 0.00 & 1.49 & 0.00 & 4.22 & 0.00 \\
$\mathbf{2}$ & 10.2 & 0.62 & 20.2 & 0.03 & 1.61 & 1.17 & 23.1 & 0.27 \\
$\mathbf{3}$ & 31.5 & 1.50 & 19.6 & 1.41 & 17.1 & 4.41 & 25.2 & 1.37 \\
$\mathbf{4}$ & 25.5 & 4.80 & 28.9 & 1.75 & 13.8 & 5.39 & 26.9 & 1.41 \\
$\mathbf{5}$ & 29.9 & 4.47 & 33.2 & 2.90 & 13.5 & 5.26 & 29.5 & 1.37 \\
\hline
\end{tabular}

In this context, India is an outlier in the region, as host economic fluctuations explain little variance in remittances to the country. However, just like other countries in the region, India's home output does not account for a substantial part of variance in the country's remittance receipts. This negligible role of either home or host GDP in the case of India found here points to the possibility that the volume of remittances to India does not react to macroeconomic factors and overseas Indians remit back home considering local microeconomic situation.

\section{Concluding Remarks}

In this study, we examined the business cycle properties of remittances to the four principal South Asian economies over the last four decades. We find that remittances to the region usually indicate no significant cyclical behaviour. This is manifested in the acyclical behaviour of the two major economies of the region: India and Pakistan. Remittances to the two countries are mostly acyclical with respect to the host region business cycles, and countercyclical with respect to the home output. The latter relationship accounts for a minor proportion of the variation in remittances. These results indicate that remittance flows to India and Pakistan mainly respond to household and individual concerns, and do not substantially alter due to macroeconomic situation prevalent at a given time.

In contrast, Bangladesh and Sri Lanka show mixed remittance behaviour, with remittance flows usually procyclical both with respect to the home and the host economies. This divergence between the South Asian countries may owe to the different degree of importance of remittances in each country's economy. Bangladesh and Sri Lanka rely proportionally more on remittances, with the flows often representing ten percent of the national output. India and Pakistan, on the other hand, have larger economies with remittances accounting for only 3 and 6 percent of the GDP. This differential behaviour indicates that remittance behaviour across developing countries, even with similar economic structures and cultural heritage, varies with the size of the home economy. Subsequently, there may exist a threshold level of remittance flows as a share of the home GDP, below which the remittances are not affected by the business cycles.

Another key insight is that specificities of the host regions' economies play little role in determining the cyclical properties of remittances to South Asian countries. A country's migrant communities in various host regions may differ in their socioeconomic profiles, but their remittance behaviours are quite similar when compared with the migrant communities of the other countries. This finding highlights the importance of conducting country studies for examining the role of migrant remittances in the developing economies. 


\section{References:}

Ahmed, J. (2012). "Cyclical Properties of Migrant's Remittances to Pakistan: What the data tell us”, Economics Bulletin, AccessEcon, vol. 32(4), pages 3266-3278.

Akkoyunlu, S \& Kholodilin, K. (2008). “A link Between Workers' Remittances and Business Cycles in Germany and Turkey", Emerging Markets Finance \& Trade, 44, pp.23-40.

Anwar, A.I. and Mughal, M.y. (2012) "Motives to remit: Some micro evidence from Pakistan", Economic Bulletin, Volume 32, No. 1, pp.574-585

Baxter, M and King, R G (1999), "Measuring Business Cycles: Approximate Band-Pass Filters for Economic Time Series", The Review of Economics and Statistics, 81, pp. 575-593.

Barua, S., Majumder, M.A., \& Akhtaruzzaman, Md. (2007). Determinants of Worker's Remittances in Bangladesh: An Empirical Study. Working Paper 0713, Policy Analysis Unit, Bangladesh Bank.

Bernanke, B. (1986), "Alternative explorations of the money-income correlation”, Carnegie-Rochester Series on Public Policy, 25, pp. 49-99.

Blanchard, O.J., and D.T. Quah (1989). The Dynamic Effects of Aggregate Demand and Supply Disturbances. The American Economic Review 79 (4): 655-673

Blanchard, O.J. and M.W. Watson, (1986), “Are Business Cycles All Alike”?, in Gordon, R. (ed.), The American Business Cycle: Continuity and Change, University of Chicago Press, Chicago, pp. 123-56.

Cooray, A. (2012) "The Impact of Migrant Remittances on Economic Growth: Evidence from South Asia." Review of International Economics, 20(5), 985-998, 2012

Corbae, D., Ouliaris, S. and Phillips, P.C.B. (2002) "Band Spectral Regression with Trending Data", Econometrica, 70, pp. 1067-1109.

Corbae, D. and Ouliaris, S. (2006), "Extracting Cycles from Nonstationary Data", in Corbae, D, Durlauf, S N and Hansen, B E (eds.), Econometric Theory and Practice: Frontiers of Analysis and Applied Research, Cambridge University Press.

Coronado, R.A. (2009), "Business Cycles and Remittances: Can the Beveridge-Nelson Decomposition Provide New Evidence?" Federal Reserve Bank of Dallas Globalization and Monetary Policy Institute Working Paper No. 40

Frankel, J.A. (2009), “Are bilateral remittances countercyclical?” NBER Working Paper 154191050 Massachusetts Avenue Cambridge, MA 02138 October 2009.

Gali, J. (1992), "How Well Does the IS-LM Model Fit Postwar US Data?" Quarterly Journal of Economics 107 (2): 709-738.

Gottschalk, J. (2001), “An Introduction into the SVAR Methodology: Identification, Interpretation and Limitations of SVAR Models", Kiel Institite for World Economics, WP 1072

Gujarati, D. (2004), Basic Econometrics, Fourth Edition, The McGraw-Hill Companies

Gupta P. 2005. Macroeconomic determinants of remittances: evidence from India. IMF Working Paper number 224, International Monetary Fund, Washington D.C.

Henk, C., Kranendonk, J.B. and Verbruggen, J.P. (2004), "A Leading Indicator for the Dutch Economy Methodological and Empirical Revision of the CPB System”, CESifo Group Munich, CESifo Working Paper Series No. 1200.

Hodrick, R.J. and Prescott, E.C. (1997), "Post-war U.S. Business-Cycles: An EmpiricalInvestigation", Journal of Money, Credit and Banking, 29(1), pp. 1-16.

Ahmed, J (2012), "Cyclical Properties of Migrants Remittances to Pakistan: What the data tell us", Economic Bulletin, Vol.32 No.4 pp.3266-3278.

Lueth, E. and Ruiz-Arranz, M. (2006), “A Gravity Model of Workers’ Remittances”, International Monetary Fund Working Papers.

Leuth, E. and Ruiz-Arranz, M, (2007), “Are Workers' Remittances a Hedge Against Macroeconomic Shocks? The Case of Sri Lanka", IMF Working Paper, 07/22

Ministry of Finance Pakistan (2010), Economic survey of Pakistan, Ministry of Finance, Government of Pakistan Islamabad.

Ministry of Overseas Indian Affairs ( 2009) “Annual Report 2008-09.” Government of India, New Delhi.

Mohapatra, S., Ratha, D., and Silwal, A. (2011), Outlook for Remittance Flows 2012-2014. Migration and Development Brief 17. Migration and Remittances Unit. December 1. The World Bank

Mughal, M.Y. (2012), "Remittances as development strategy: Stepping stones or slippery slope?" Journal of International Development, 24:8.

Mughal, M.Y. and Anwar, A.I. (2012), "Remittances, Inequality and Poverty in Pakistan: Macro and Microeconomic Evidence,"Working Papers 2012-2013_2, CATT - UPPA - Université de Pau et des Pays de l'Adour, revised Aug 2012.

Mughal, M.Y. and Makhlouf, F. (2011), "Volatility of remittances to Pakistan: What do the data tell?" Economics Bulletin, 31:1, pp. 605-612. 
Neagu, I.C. and Schiff, M. (2009), "Remittance stability, cyclicality and stabilizing impact in developing countries", Policy Research Working Paper Series 5077, The World Bank

Nishat, M., and Nishat B. (1993), "The Determinants of Workers' Remittances in Pakistan", The Pakistan Development Review 32:4, 1235-1245.

Sayan, S. (2004), “Guest Workers' Remittances and Output Fluctuations in Host and Home Countries: the case of Remittances from Turkish Workers in Germany", Emerging Market Finance \& Trade, 40, pp. 68-81.

Sayan, S. (2006), "Business Cycles and Workers' Remittances: How do Migrant Workers Respond to Cyclical Movements of GDP at Home?” IMF Working Paper No. 06/52, Washington, DC: IMF.

Sayan, S. and Tekin-Koru, A. (2007), "Business Cycles and Remittances: A comparison of the Cases of Turkish Workers in Germany and Mexican Workers in the US", MPRA Working Paper 6030.

Sayan, S. and Tekin-Koru, A. (2010), "Remittances, Business Cycles and Poverty: The Recent Turkish Experience", International Migration.

Shapiro, M. and Watson, M. (1988), "Sources of Business Cycles Fluctuations," in S. Fischer (ed.): NBER Macroeconomics Annual 1988, MIT Press, vol. 3, pp 111-148.

Sims, C.A. (1986), "Are Forecasting Models Usable for Policy Analysis?" Quarterly Review of the Federal Reserve Bank of Minneapolis, 10, pp. 2-16.

Suleri, A. and Savage, K. (2006), "Remittances in Crisis: A Case Study from Pakistan", Humanitarian Policy Group, Overseas Development Institute, London.

Vargas-Silva, C. (2008) "Are remittances manna from heaven? A look at the business cycle properties of remittances". North American Journal of Economics and Finance, (19), 290-303

World Bank (2006), Global Economic Prospects 2006: Economic Implications of Remittances and Migration.

Washington, DC: World Bank.

World Bank (2011), Migration and Remittances Factbook 2011. Washington, DC: World Bank.

World Bank (2012), Migration and Development Brief 18. Washington, DC: World Bank. 


\section{Appendix:}

Table A1. ADF Test Results for Unit Root:

\begin{tabular}{|c|c|c|c|c|}
\hline Variables' & Level & HP Filter & BK Filter & FD Filter \\
\hline GDP South Asia & $-1.070(0)$ & $-5.54 *(3)$ & $-6.96 *(1)$ & $-5.76 *(1)$ \\
\hline Remittances South Asia & $-3.351(0)$ & $-4.56 *(4)$ & $-3.58 *(3)$ & $-3.72 * *(1)$ \\
\hline GDP Pakistan & $-1.511(1)$ & $-4.64 *(1)$ & $-4.83 *(1)$ & $-4.53 *(1)$ \\
\hline Remittances Pakistan & $-2.633(0)$ & $-3.75 * *(9)$ & $-5.33 *(1)$ & $-5.35 *(1)$ \\
\hline GDP Bangladesh & $-1.138(5)$ & $-4.04 *(13)$ & $-4.22 *(5)$ & $-5.14 *(6)$ \\
\hline Remittances Bangladesh & $-2.865(3)$ & $-8.36 *(1)$ & $-4.07 * *(3)$ & $-5.55 *(1)$ \\
\hline GDP India & $-1.268(0)$ & $-5.90 *(3)$ & $-7.27 *(1)$ & $-5.88 *(1)$ \\
\hline Remittances India & $-1.360(1)$ & $-4.99 *(4)$ & $-7.68 *(0)$ & $-5.42 *(1)$ \\
\hline GDP Sri Lanka & $-0.530(1)$ & $-4.78 *(1)$ & $-4.90 *(1)$ & $-5.94 *(1)$ \\
\hline Remittances Sri Lanka & $-0.477(7)$ & $-3.27 *(4)$ & $-5.04 *(0)$ & $-4.13 *(1)$ \\
\hline Weighted Output (North America) & $-1.589(0)$ & $-4.58 *(6)$ & $-4.74 *(1)$ & $-4.56 *(1)$ \\
\hline Weighted Output (GCC) & $-2.274(0)$ & $-4.73 *(0)$ & $-5.05 *(0)$ & $-4.88 *(1)$ \\
\hline Weighted Output (Europe) & $-1.566(1)$ & $-3.97 * *(8)$ & $-5.34 *(1)$ & $-4.82 *(1)$ \\
\hline Weighted Output (Pacific Asia) & $-1.937(0)$ & $-4.44 *(6)$ & $-5.60 *(1)$ & $-4.09 *(1)$ \\
\hline
\end{tabular}

ADF represents the Augmented Dickey-Fuller unit root test with trends for the original and the detrended series. Asterisk,* represents

$1 \%$ level of significance and ** represents $5 \%$ level of significance. For Lag length selection, AIC criterion was used. 